\title{
MICROMORPH SOLAR CELL OPTIMIZATION USING A ZnO LAYER AS INTERMEDIATE REFLECTOR
}

\author{
D. Dominé, J. Bailat, J. Steinhauser, A. Shah, C. Ballif \\ Institute of Microtechnology, University of Neuchâtel, Breguet 2, CH-2000 Neuchâtel, Switzerland \\ Contact author: didier.domine@unine.ch \\ tel: (+)41327183312; fax: (+)41327183201
}

\begin{abstract}
The insertion of a zinc oxide $(\mathrm{ZnO})$ intermediate reflector (ZIR) between the top and bottom cell of a superstrate $(p-i-n / p-i-n)$ micromorph tandem solar cell is analyzed, experimentally and by numerical simulation. Solar cells are deposited onto glass plates coated by surfacetextured $\mathrm{ZnO}$ layers deposited by low-pressure chemical vapour deposition (LP-CVD). The gain in the top cell shortcircuit current density $\left(\mathrm{J}_{\mathrm{sc}}\right)$ obtained by ZIR insertion as well as the corresponding loss for the bottom cell are experimentally observed, for different values of ZIR thickness $\mathrm{d}$. The gain and the loss depend nearly linearly on ZIR thickness for $d<100 \mathrm{~nm}$, the maximum gain is almost $3 \mathrm{~mA} / \mathrm{cm}^{2}$. Experimental results are compared with an optical simulation. In the latter a three-layer effective media approximation is used for modeling of thin ZIR layers. Micromorph tandem solar cells were deposited on 2 different types of front LP-CVD ZnO layers: (a) a layer optimized for a-Si:H single-junction solar cells; (b) ZnO layers specially developed for $\mu \mathrm{c}-\mathrm{Si} \mathrm{H}$ cells and having undergone a novel surface treatment. In case (a) $J_{s c}=12.1$ $\mathrm{mA} / \mathrm{cm}^{2}$ and initial conversion efficiency is $11.6 \%$; in case (b) $\mathrm{J}_{\mathrm{sc}}=12.8 \mathrm{~mA} / \mathrm{cm}^{2}$ and initial conversion efficiency is $11.8 \%$. The open-circuit voltage $\left(\mathrm{V}_{\mathrm{oc}}\right)$ value could be improved from $1.32 \mathrm{~V}$ to $1.41 \mathrm{~V}$ with an increased surface treatment time.
\end{abstract}

\section{INTRODUCTION}

The insertion of an intermediate reflector between the amorphous silicon (a-Si:H) top cell and the microcrystalline silicon ( $\mu \mathrm{c}-\mathrm{Si}: \mathrm{H})$ bottom cell of the "micromorph" tandem solar cell [1] increases the value of the top cell shortcircuit current density $\left(\mathrm{J}_{\mathrm{sc}}\right)$, allowing for a reduction of its thickness and, thereby, for an attenuation of the StaeblerWronski effect [2,3]. The concept of an intermediate reflector was introduced by IMT in 1996 [2] and was successfully applied by Meier et al. with the demonstration of high stability (over prolonged light soaking) for a bottom-limited micromorph tandems with a thin a-Si:H top cell $(<0.2 \mu \mathrm{m})$ [4]. It was also applied by Yamamoto et al. who recently demonstrated an initial module efficiency of $13.5 \%$ [5].

In this paper we consider both modeling and experimental results for analyzing the situation and demonstrating how a zinc oxide ( $\mathrm{ZnO})$ intermediate reflector ( $\mathrm{ZIR}$ ) can be used to tune the value of the short-circuit current densities $\left(J_{s c}\right)$ within a superstrate $(p-i-n / p-i-n)$ micromorph tandem solar cell.

The cell is deposited onto a glass coated with a surface-textured front transparent conductive oxide (TCO). The latter being $\mathrm{ZnO}$ fabricated by low pressure chemical vapor deposition (LP-CVD). We compare the performance of micromorph tandem cells integrating a ZIR layer, deposited onto 2 different kinds of front TCO layers: (a) onto our standard LP-CVD ZnO layer optimized for a-Si:H solar cells; (b) onto new LP-CVD ZnO layers specially developed for $\mu \mathrm{c}-\mathrm{Si} \mathrm{H}$ solar cells. These new $\mathrm{ZnO}$ layers have a lower free carrier absorption (FCA) and an higher rootmean-square (RMS) value of surface roughness ( $\sigma_{\mathrm{RMS}}$ ) than our standard layer $[6,7]$. Their surface morphology is, furthermore, modified by a novel surface treatment to render it more suitable for the growth of $\mu \mathrm{c}-\mathrm{Si}: \mathrm{H}$ [7]. The effect of this surface treatment is studied for the case of micromorph tandem cells.

\section{EXPERIMENTAL}

\section{Device fabrication and characterization}

The sheet resistance of the different front LP-CVD layers used in this work is approximately $10 \Omega /$. Their $\sigma_{\text {RMs }}$ and feature size values were determined by atomic force microscopy (AFM) measurements performed in the non-contact mode.

The ZIR layers deposited here have thickness values ranging from $16 \mathrm{~nm}$ to $330 \mathrm{~nm}$ and are either $\mathrm{ZnO}: \mathrm{Al}$ layers deposited by RF-sputtering or LP-CVD ZnO:B layers.

The a-Si:H $(180 \mathrm{~nm})$ and $\mu \mathrm{c}-\mathrm{Si}: \mathrm{H}(1.8 \mu \mathrm{m})$ layers were deposited by very-high frequency plasma enhanced chemical vapor deposition (VHF-PECVD) (see also [8]).

The back contact consists of a LP-CVD ZnO layer covered with a dielectric back reflector. For some experiments the back reflector is not used. The cell area was patterned by laser scribing $\left(25 \mathrm{~mm}^{2}\right)$ or by $\mathrm{SF}_{6}$ plasma etching $\left(\sim 20 \mathrm{~mm}^{2}\right)$.

The current density-voltage (JV) curves were measured using an AM1.5 sun simulator (Wacom). The external quantum efficiencies (EQE) of the top and bottom cells were measured under red and blue bias-light illumination, respectively. Short-circuit current densities for top cell $\left(\mathrm{J}_{\mathrm{sc}, \text { top }}\right)$ and bottom cell $\left(\mathrm{J}_{\mathrm{sc}, \text { bottom }}\right)$ were calculated from the EQE curves, by integrating, over the wavelength range, 
the product of EQE times the spectral density of the photon flux of AM1.5 solar spectrum.

\section{Optical modeling}

Optical effects of ZIR are studied by means of optical modeling and by calculation of the optical absorption of the various layers within the device. The computer program used includes coherent calculation, scalar scattering theory and Monte Carlo tracing of scattered light [9] as well as experimentally determined wavelength-dependent optical constants [10]. Under the assumption of $100 \%$ collection efficiency, the optical absorption in the top and bottom absorbers permits us to determine the projected increase and decrease in $J_{\text {sc,top }}$ and $J_{\text {sc,bottom, respectively, }}$ as caused by ZIR insertion (designated as $\delta \mathrm{J}_{\text {sc,top }}$ and $\delta J_{\text {sc, bottom, respectively). }}$

For the textured interfaces, a one-layer effective media approximation (EMA) is used [10]. For a ZIR layer with a thickness value $d<\sigma_{\mathrm{RMS}}$, a three-layer EMA is used: the a-Si:H / ZIR / $\mu \mathrm{C}-\mathrm{Si}: \mathrm{H}$ region is subdivided into three zones (1), (2) and (3) of thickness $d, \sigma_{R M S}-d$ and d, respectively. The volume of zone (1) is occupied by a-Si:H and $\mathrm{ZnO}$, the volume of zone (2) is a mix of the 3 materials and the volume of zone (3) is occupied by $\mathrm{ZnO}$ and $\mu \mathrm{c}-\mathrm{Si}: \mathrm{H}$. The corresponding effective refractive indexes $\tilde{n}_{1}, \tilde{n}_{2}$ and $\tilde{n}_{3}$, are calculated as the weighted sum of the refractive indexes of a-Si:H, $\mathrm{ZnO}$ and $\mu \mathrm{c}-\mathrm{Si}: \mathrm{H}$. The weighting coefficients are calculated as the volume fractions of these materials in zone (1), (2) and (3), supposing homogenous coverage of the surface by the same pyramidal structures.

\section{RESULTS}

\section{ZIR thickness-effect for a given type of front $\mathrm{ZnO}$}

The ZIR thickness $\mathrm{d}$ was varied from $16 \mathrm{~nm}$ to 327 $\mathrm{nm}$ inside the tandem cells (without back reflector) deposited on front LP-CVD ZnO layers with a surface roughness $\sigma_{\text {RMs }}$ of approximately $80 \mathrm{~nm}$. The experimental difference in $\mathrm{J}_{\mathrm{sc}}$ values obtained with and without the ZIR layer (des-

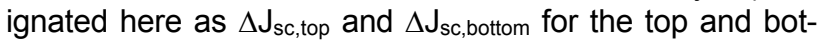
tom cells, respectively) are compared with simulated results in Fig. 1.

The experimental gain $\Delta \mathrm{J}_{\text {sc,top }}$ increases with a slope of approximately $0.03 \mathrm{~mA} / \mathrm{cm}^{2}$ per $\mathrm{nm}$ of ZIR thickness. The maximum gain obtained is $2.8 \mathrm{~mA} / \mathrm{cm}^{2}$ for $\mathrm{d}=110 \mathrm{~nm}$. For higher $\mathrm{d}$ values, $\Delta \mathrm{J}_{\mathrm{sc} \text {,top }}$ remains in the range of 1.8 to

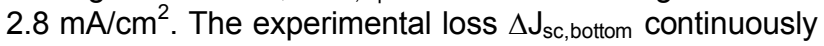
decreases when $\mathrm{d}$ increases. Assuming a linear approximation for this trend for $d<100 \mathrm{~nm}$, its slope is approximately $-0.04 \mathrm{~mA} / \mathrm{cm}^{2}$ per $\mathrm{nm}$ of ZIR thickness.

\section{Optical modeling}

When $d$ increases, the simulated gain $\delta J_{\text {sc,top }}$ in the top cell increases up to $2.3 \mathrm{~mA} / \mathrm{cm}^{2}$, followed by a saturation for $d>\sigma_{\text {RMs }}(80 \mathrm{~nm})$. Reversely, the simulated loss $\delta \mathrm{J}_{\mathrm{sc} \text {,bottom }}$ in the bottom cell decreases rapidly down to -3.4 $\mathrm{mA} / \mathrm{cm}^{2}$ for $\mathrm{d}=80 \mathrm{~nm}$ and then continues to decrease less steeply (see Fig. 1).
One may compare these results with those obtained for flat interfaces (verified experimentally in [3]) which demonstrate the interferential behavior of a flat ZIR but

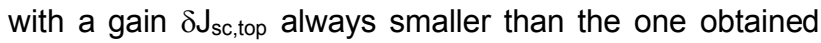
for rough interfaces (see Fig. 1).

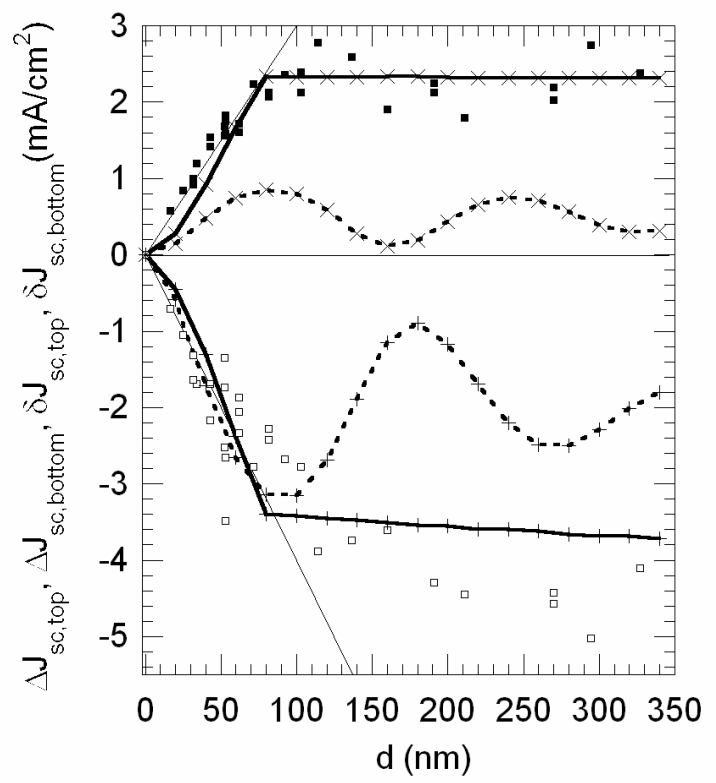

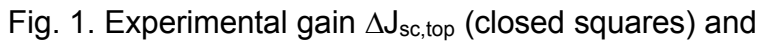

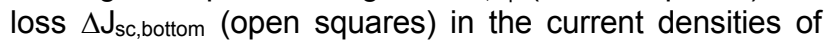
top and bottom cells, respectively, as a function of ZIR thickness $\mathrm{d}$. The full lines correspond to the simulated gain $\delta \mathrm{J}_{\text {sc,top }}(\mathrm{x})$ and loss $\delta \mathrm{J}_{\text {sc,bottom }}(+)$ for rough interfaces and the dashed lines correspond to the simulated results for the case of the flat interfaces. The two continuous hairlines indicate the slopes $\left(0.03 \mathrm{~mA} / \mathrm{cm}^{2}\right.$ and $-0.04 \mathrm{~mA} / \mathrm{cm}^{2}$ per $\mathrm{nm}$ ) observed experimentally for small values of $d$.

\section{Roughness and feature size effect}

We observed previously that the experimental gain $\Delta \mathrm{J}_{\text {sc,top }}$ and loss $\Delta \mathrm{J}_{\mathrm{sc} \text {,bottom }}$ obtained by insertion of a $30 \mathrm{~nm}$ thick ZIR remain constant $\left(1.0 \mathrm{~mA} / \mathrm{cm}^{2}\right.$ and $-1.4 \mathrm{~mA} / \mathrm{cm}^{2}$, respectively) when the $\sigma_{\mathrm{RMS}}$ value of the front LP-CVD $\mathrm{ZnO}$ layer varies from $60 \mathrm{~nm}$ to $109 \mathrm{~nm}$ [8]. The effectiveness of thin ZIR is therefore not affected by interfaces roughness with $\sigma_{\mathrm{RMS}}$ values between these two limits.

With our novel surface treatment for LP-CVD ZnO layers [7] it is now possible to successfully deposit micromorph tandem cells on rougher front TCO layers, without incurring dramatic losses in open-circuit voltage $\left(\mathrm{V}_{\mathrm{oc}}\right)$ and fill-factor (FF) [11]. Micromorph tandems deposited on 2 strongly different front LP-CVD ZnO layers with $\sigma_{\mathrm{RMS}}$ values of 69 and $276 \mathrm{~nm}$ and feature sizes of $360 \mathrm{~nm}$ and $1.05 \mu \mathrm{m}$, respectively, are compared in Fig. 2. In both cases a $90 \mathrm{~nm}$ thick ZIR layer is inserted and a back reflector is used. When the tandem is deposited onto the highly-textured front TCO, $\mathrm{J}_{\mathrm{sc}, \text { top }}$ decreases from 12.4 to $10.7 \mathrm{~mA} / \mathrm{cm}^{2}(-14 \%)$ and the sum of the $J_{\mathrm{sc}}$ values of top and bottom cells increases from $22.1 \mathrm{~mA} / \mathrm{cm}^{2}$ to 23.2 
$\mathrm{mA} / \mathrm{cm}^{2}(+5 \%)$, as compared to the less textured substrate. In this comparison, the very strong increase of surface texture implies a $14 \%$ reduction in $\mathrm{J}_{\mathrm{sc} \text {,top }}$, corresponding to a decrease of the top cell EQE in the $500-750 \mathrm{~nm}$ spectral range (see Fig. 2).

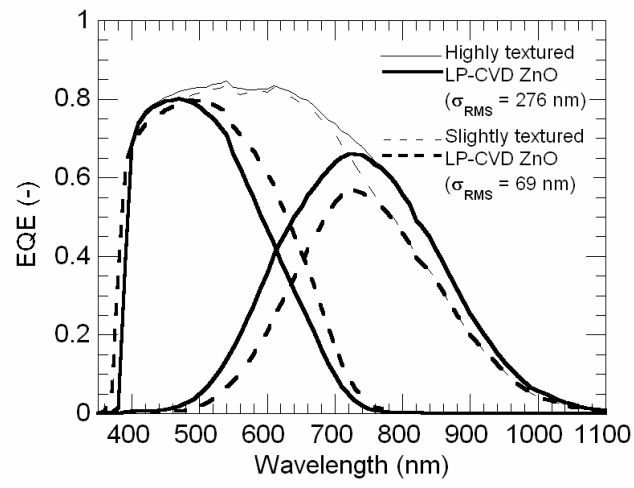

Fig. 2. Comparison of EQE curves of a-Si:H top and $\mu \mathrm{C}-$ Si:H bottom cells of micromorph tandems with a $90 \mathrm{~nm}$ thick ZIR layer and back reflector. The tandems are deposited on two different front TCO layers, with $\sigma_{\mathrm{RMS}}$ values of $69 \mathrm{~nm}$ and $276 \mathrm{~nm}$. One finds: $J_{\mathrm{sc}, \text { top }}=12.4 \mathrm{~mA} / \mathrm{cm}^{2}$, $\mathrm{J}_{\text {sc,bottom }}=9.7 \mathrm{~mA} / \mathrm{cm}^{2}$ for slightly-textured $\mathrm{TCO}$ and $\mathrm{J}_{\mathrm{sc}, \text { top }}=10.7 \mathrm{~mA} / \mathrm{cm}^{2}, \quad \mathrm{~J}_{\mathrm{sc}, \text { bottom }}=12.5 \mathrm{~mA} / \mathrm{cm}^{2}$ for highlytextured TCO.

\section{Front LP-CVD ZnO surface treatment}

Single-junction p-i-n a-Si:H solar cells with $180 \mathrm{~nm}$ thick intrinsic layers were deposited onto front LP-CVD ZnO layers specially developed for $\mu \mathrm{c}-\mathrm{Si}: \mathrm{H}$ p-i-n solar cells, thereby employing different surface treatment times. $V_{o c}$ and FF of the a-Si:H cells improved with the duration of the treatment, while $\mathrm{J}_{\mathrm{sc}}$ decreased. Without surface treatment, the values of $\mathrm{V}_{\mathrm{oc}}$, FF and $\mathrm{J}_{\mathrm{sc}}$ were $868 \mathrm{mV}, 72.3 \%$ and $15.18 \mathrm{~mA} / \mathrm{cm}^{2}$, respectively. By applying a 60 minute surface treatment to the front LP-CVD $\mathrm{ZnO}$ layer, $\mathrm{V}_{\mathrm{oc}}$ and FF increased to $927 \mathrm{mV}$ and $75.1 \%$, respectively, while $\mathrm{J}_{\mathrm{sc}}$ decreased to $14.65 \mathrm{~mA} / \mathrm{cm}^{2}$. The initial conversion efficiency is thereby improved from $9.5 \%$ to $10.2 \%$ by the surface treatment of 60 minutes' duration (Table 1).

\begin{tabular}{|c|c|c|c|c|c|}
\hline \multirow{2}{*}{$\begin{array}{l}\text { Treatment } \\
\text { time } \\
(\min )\end{array}$} & \multicolumn{4}{|c|}{ Single-junction a-Si:H } & \multirow{2}{*}{$\begin{array}{c}\text { Micromorph } \\
\mathrm{V}_{\mathrm{oc}} \\
(\mathrm{mV})\end{array}$} \\
\hline & $\begin{array}{l}\text { FF } \\
(\%)\end{array}$ & $\begin{array}{l}\mathrm{V}_{\mathrm{oc}} \\
(\mathrm{mV})\end{array}$ & $\begin{array}{c}\mathrm{J}_{\mathrm{sc}} \\
\left(\mathrm{mA} / \mathrm{cm}^{2}\right.\end{array}$ & $\begin{array}{l}\text { Eff } \\
(\%)\end{array}$ & \\
\hline 0 & 72.3 & 868 & 15.2 & 9.54 & 1322 \\
\hline 20 & 75.0 & 896 & 14.8 & 9.95 & 1392 \\
\hline 30 & - & - & - & - & 1411 \\
\hline 40 & 74.8 & 909 & 14.6 & 9.93 & - \\
\hline 60 & 75.1 & 927 & 14.6 & 10.2 & - \\
\hline
\end{tabular}

Table 1. Electrical characteristics of single-junction a-Si:H solar cells and $V_{\text {oc }}$ values of micromorph tandem cells with a novel surface treatment used on the front LP-CVD $\mathrm{ZnO}$, for different durations of the surface treatment $(0$ minute stands for "no surface treatment").
In the micromorph configuration, both the top and bottom cells benefit by the favorable surface morphology obtained on the front LP-CVD ZnO layer, by our novel surface treatment. The latter is, thus, efficient in increasing $V_{\text {oc }}$ of micromorph tandem solar cells. Table 1 shows the evolution of the $V_{\text {oc }}$ values of tandem cells with respect to the duration of the surface treatment. 30 minutes indeed improves $\mathrm{V}_{\text {oc }}$ from $1.32 \mathrm{~V}$ to $1.41 \mathrm{~V}$.

The surface treatment influences the tandem current densities: a decrease of $0.45 \mathrm{~mA} / \mathrm{cm}^{2}$ in $\mathrm{J}_{\mathrm{sc}, \text { top }}$, and an increase of $0.26 \mathrm{~mA} / \mathrm{cm}^{2}$ in $\mathrm{J}_{\mathrm{sc} \text {,bottom }}$ were observed for a 40 minute treatment time.

\section{Cell optimization}

The linear dependence of $\Delta \mathrm{J}_{\text {sc,top }}$ and $\Delta \mathrm{J}_{\text {sc,bottom with }}$ ZIR thickness, experimentally observed for ZIR layers thinner than $100 \mathrm{~nm}$ and for front TCO layers with $\sigma_{\mathrm{RMS}}$ values between 60 and $110 \mathrm{~nm}$, can be used as a design tool to determine the ZIR thickness required to obtain slightly bottom-limited micromorph tandem cells.

With our standard front LP-CVD ZnO layer optimized for a-Si:H solar cells and with top and bottom cell thicknesses of $180 \mathrm{~nm}$ and $1.8 \mu \mathrm{m}$, respectively, we succeeded, by the insertion of a $50 \mathrm{~nm}$ thick ZIR, in obtaining a bottom-limited tandem with $\mathrm{J}_{\mathrm{sc}}=12.1 \mathrm{~mA} / \mathrm{cm}^{2}, \mathrm{~V}_{\mathrm{oc}}=1315$ $\mathrm{mV}$ and $\mathrm{FF}=73.2 \%$, yielding an initial conversion efficiency of $11.6 \%$. The sum of the $\mathrm{J}_{\mathrm{sc}}$ values of this tandem is $24.5 \mathrm{~mA} / \mathrm{cm}^{2}$.

With the new front LP-CVD ZnO layers developed for

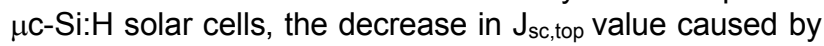
the increased surface texture of the front LP-CVD ZnO (see Fig. 2) and by the novel surface treatment has to be taken into account. By increasing the top and bottom cell thicknesses to $290 \mathrm{~nm}$ and $3.0 \mu \mathrm{m}$, respectively, and with a short 10 minute surface treatment of the front LP-CVD $\mathrm{ZnO}$, we succeeded, with the insertion of a $50 \mathrm{~nm}$ thick ZIR, to obtain a bottom-limited tandem cell with $\mathrm{J}_{\mathrm{sc}}=12.8 \mathrm{~mA} / \mathrm{cm}^{2}$ (bottom cell $13.2 \mathrm{~mA} / \mathrm{cm}^{2}$ ), $\mathrm{V}_{\text {oc }}=1315 \mathrm{mV}$ and $\mathrm{FF}=70.2 \%$, yielding an initial conversion efficiency of $11.8 \%$. The EQE curves are presented in Fig 3.

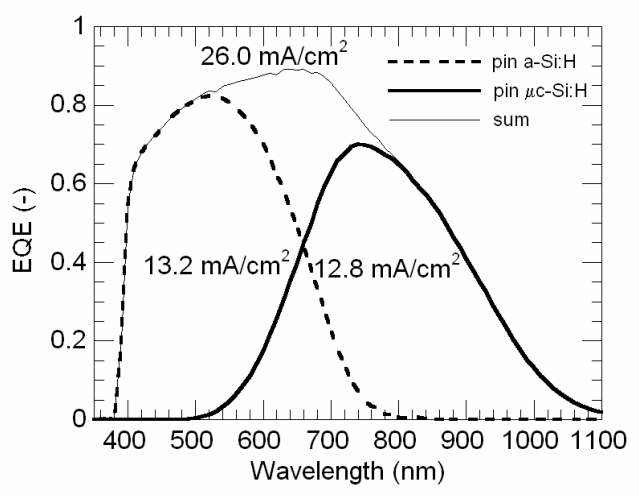

Fig. 3. EQE curves of the top and bottom cells of a micromorph tandem solar cell optimized on the new front LP. CVD ZnO. 


\section{DISCUSSION}

\section{ZIR thickness-effect for a given type of front $\mathrm{ZnO}$}

For ZIR thicknesses $d<100 \mathrm{~nm}$, we observed here that the slopes of the linear trends are $0.03 \mathrm{~mA} / \mathrm{cm}^{2}$ and $-0.04 \mathrm{~mA} / \mathrm{cm}^{2}$, respectively, per $\mathrm{nm}$ of ZIR thickness. These values are useful for the prediction of the top and bottom current densities when varying $d$. A ZIR thickness larger than $100 \mathrm{~nm}$ may not be favorable as the loss $\Delta \mathrm{J}_{\text {sc,top }}$ then gets continuously larger.

\section{Optical modeling}

The three-layer EMA model for thin ZIR succeeds in predicting a gradual change in $\delta J_{s c, \text { top }}$ and $\delta J_{\text {sc,bottom when }}$ $\mathrm{d}$ increases up to the $\sigma_{\mathrm{RMS}}$ value of the interfaces. The discontinuity obtained when $d$ reaches the $\sigma_{R M S}$ value is obviously produced by a discontinuity in the model, since the effective refractive indexes stop changing at this point.

A wavelength-dependent EMA model may be better suited for addressing the situation arising with rough interfaces with large feature size (see next section).

\section{Roughness and feature size effect}

The gain of $5 \%$ obtained for the sum of the $\mathrm{J}_{\mathrm{sc}}$ values of the tandem with rougher front $\mathrm{ZnO}$ surfaces (see Fig. 2) is the consequence of enhanced light-scattering effects in the infrared part of the spectrum. This shows the substantial advantage of using a very rough front TCO for $\mu \mathrm{c}-\mathrm{Si}: \mathrm{H}$ and micromorph solar cells. The challenge here is to overcome the reduction observed for $\mathrm{J}_{\text {sc,top }}(14 \%)$.

For comparison, single-junction a-Si:H solar cells present a $\mathrm{J}_{\mathrm{sc}}$ loss of only $5 \%$ when deposited on these highly-textured $\mathrm{ZnO}$ layers. This $5 \%$ loss corresponds to a decrease of EQE in the $550-700 \mathrm{~nm}$ spectral range, and is probably caused by (i) a decrease in the effective intrinsic absorber thickness when deposited onto a very rough front TCO and (ii) a decrease of the light-trapping capability in the 550-700 nm spectral range when the front TCO has very high feature size value.

In addition to (i) and (ii), another cause must be involved in the $14 \%$ reduction observed for $\mathrm{J}_{\text {sc,top. }}$. We suggest that this may be linked to a decrease of the ZIR effectiveness for large $\sigma_{\text {RMS }}$ and feature size values.

\section{Front LP-CVD ZnO surface treatment}

The treatment of the front LP-CVD ZnO is very effective in increasing the $V_{o c}$ values of micromorph tandem cells, up to $1.41 \mathrm{~V}$.

The decrease in $J_{s c}$ value observed here for a-Si:H single-junction solar cell is caused by a smoothening of the surface roughness with increasing treatment time as measured by AFM. For $\mu \mathrm{c}-\mathrm{Si}: \mathrm{H}$ single-junction solar cells this decrease in $\mathrm{J}_{\mathrm{sc}}$ is also observed [7] but it takes place for treatment time longer than 40 minutes. This explains why, for micromorph tandem cells, the 40 minute treatment time changes the balance between $J_{\text {sc,top }}$ and $J_{\text {sc,bottom. }}$

\section{Cell optimization}

With the novel front LP-CVD ZnO layers developed for $\mu \mathrm{c}-\mathrm{Si}: \mathrm{H}$ solar cells, the sum of the top and bottom cell $\mathrm{J}_{\mathrm{sc}}$ values is $26 \mathrm{~mA} / \mathrm{cm}^{2}$ which corresponds to an improvement of $6 \%$ compared to the thinner tandem deposited onto the front TCO layer optimized for a-Si:H cells.

Matched current density of $13 \mathrm{~mA} / \mathrm{cm}^{2}$ is then directly achievable with the new TCO. This value was, at present, achieved with a short treatment time (10 minutes) applied to the LP-CVD ZnO layer.

Further increase of treatment time may possibly further improve the $\mathrm{V}_{\mathrm{oc}}$ and $\mathrm{FF}$ values and bring, thus, the tandem efficiency over $12 \%$.

\section{CONCLUSIONS}

The insertion of a ZIR layer provides a controlled gain in the current density of the top cell within a micromorph tandem. The maximum gain is almost $3 \mathrm{~mA} / \mathrm{cm}^{2}$. For a micromorph tandem with a thin a-Si:H top cell $(180 \mathrm{~nm})$ and a $1.8 \mu \mathrm{m}$ thick $\mu \mathrm{c}-\mathrm{Si}: \mathrm{H}$ bottom cell, the insertion of the ZIR layer allowed us to achieve a $\mathrm{J}_{\mathrm{sc}}$ value of 12.1 $\mathrm{mA} / \mathrm{cm}^{2}$.

Using our "novel" front LP-CVD ZnO optimized for $\mu \mathrm{C}-$ Si:H cells, we obtained a $J_{s c}$ value of $12.8 \mathrm{~mA} / \mathrm{cm}^{2}$ with a top cell thickness of $290 \mathrm{~nm}$ and a bottom cell thickness of $3.0 \mu \mathrm{m}$, This yielded an initial conversion efficiency of $11.8 \%$, with a total current density of $26 \mathrm{~mA} / \mathrm{cm}^{2}$.

The new surface treatment applied to the front LPCVD $\mathrm{ZnO}$ layer permitted us to improve the $\mathrm{V}_{\text {oc }}$ value from $1.32 \mathrm{~V}$ to $1.41 \mathrm{~V}$, for unmatched micromorph tandems. We therefore conclude that we now have all the individual "ingredients" needed to fabricate micromorph tandems with stable conversion efficiencies higher than $12 \%$.

\section{ACKNOWLEDGEMENTS}

The authors thank the Swiss Federal Energy Office (OFEN) for support under grant 101191; they are indebted to $M$. Vanecek and J. Springer for providing the optical simulation program.

\section{REFERENCES}

[1] J. Meier et al., 1st WCPEC, 1994, p. 409.

[2] D. Fischer et al., 25th IEEE PVSC, 1996, p. 1053.

[3] N. Pellaton Vaucher et al., 2nd WCPEC, 1998, p. 728.

[4] J. Meier et al., 3rd WCPEC, 2003, p. 2801.

[5] K. Yamamoto et al., 15th International PVSEC, 2005, p. 529.

[6] J. Steinhauser et al., 20th EU PVSEC, 2005, p. 1608.

[7] J. Bailat et al., 4th WCPEC, 2006.

[8] D. Dominé et al., 20th EU PVSEC, 2005, p. 1600.

[9] J. Springer et al., J. Appl. Phys. 96 (2004) 5329.

[10] A. Poruba et al., J. Appl. Phys. 88 (2000) 6436.

[11] L. Feitknecht et al., 15th International PVSEC, 2005, p. 473. 